\title{
10 In the Mirror of Rembrandt and the Perspectives of Others
}

\begin{abstract}
Chapter 10 discusses Visser 't Hooft's use of Rembrandt as a mirror for his favourite themes. He recognised profound biblical truths in both the life of the painter and his work. The chapter explores several of these themes. It also traces the sometimes extremely divergent opinions other people had of him. While some could find no wrong in anything he did, others could be quite critical of his approach and style of leadership.
\end{abstract}

Keywords: Rembrandt, conviction, honorary accolades, critiques of others, summing up

\subsection{Introduction}

In the summer of 1985 , a life that had been inextricably intertwined with the history of the ecumenical movement in the twentieth century came to an end. Even though Visser 't Hooft had withdrawn from public life in his last year, he was very well known at that time and was a symbol for many of a particular era in church history. More than any other church leader, he had succeeded in thinking and acting, at a global level, from the perspective of the notion of the fundamental unity of the church as a socially relevant concept. Under his leadership, the World Council of Churches grew into a player on the world stage. But even though the World Council was gaining new members, the restrictions of that model were clear already when he retired in 1966. His name had been synonymous with renewal for years, but that association gradually diminished in the last two decades of his life. For some, he remained the figurehead of the golden age of ecumenicity, for others he became the representative of an antiquated way of thinking in institutions and a model of the church that belonged to the past. This tension will be evaluated below in a series of sketches of his life. During his

Zeilstra, Jurjen A., Visser 't Hooft, 1900-1985: Living for the Unity of the Church. Amsterdam, Amsterdam University Press 2020 DOI: $10.5117 / 9789463726832$ CH1O 
lifetime, Visser 't Hooft had received many accolades. What role did they play? (10.2). Rembrandt had tremendous significance for Visser 't Hooft's understanding of himself. It was through his publications on Rembrandt that his readers came to know Visser't Hooft (10.3). Why was it that, despite the fact that he wanted to encourage people in their struggles, he did not always do so? (10.4). When he died on 4 July 1985 , many people attempted to describe Visser 't Hooft by looking back on his life (10.5).

\subsection{Honouring 'The Man of all Jobs and Odd Jobs'}

Visser't Hooft was probably the most well-known Dutch theologian outside the Netherlands in the twentieth century - certainly in Protestant circles. In this regard, only Abraham Kuyper (1837-1920) and Edward Schillebeeckx are comparable figures. Many associated Visser't Hooft with the World Council of Churches or the ecumenical movement and, around 1960, saw him as the force behind a second reformation, with some even viewing him as having completed the Reformation that had begun in the early $16^{\text {th }}$ century. Even before the war, the University of Aberdeen had bestowed on him an honorary degree on 29 March 1939. Many accolades followed, including Princeton (1950), Trinity College Toronto (1950), Geneva (1951), Yale (1954), Oberlin College Ohio (1954), Oxford (1955), Harvard (1958), Cambridge (1958), Union Theological Seminary in New York (1959), St. Paul's University in Tokyo (1959), Paris (1963), Kirchliche Hochschule in Berlin (1964), Brown University on Rhode Island (1965), the Theological Faculty of the University of Zurich (1966), the Catholic University of Leuven (1967), and the Hebrew University in Jerusalem (1972). ${ }^{1}$ Honorary professorships were awarded by Budapest (1946) and the Theological Academy of Moscow (1964). Visser 't Hooft did not view all these testimonials as laurels he could rest on. With every new honorary professorship, he enlarged his network. Guest lectures often followed. Festschriften were presented at various parties. ${ }^{2}$

Visser't Hooft and his colleagues at Vrij Nederland did not receive any royal distinctions for their work in connection with the Swiss Road, but in May 1946 he and several others who had worked in Switzerland did

1 Haarlems Dagblad, 5 February 1966. Cf. also, a list of Visser 't Hooft's honorary doctorates, without title, and undated, WCC 994.1.31.

2 The most important are Golterman and Hoekendijk (eds.), Oecumene in 't vizier. Feestbundel voor Dr. W.A. Visser't Hooft, Amsterdam 1960. Mackie and West, The Sufficiency of God. Essays in Honour of W.A. Visser 't Hooft, London 1963. Van der Bent (ed.), Voices of Unity. Essays in Honour of Willem Adolf Visser' $t$ Hooft on the Occasion of his $80^{\text {th }}$ Birthday, Geneva 1981. 
receive the Medal of Recognition 1940-1945 from Princess Juliana in Bern. This medal was given to people who had served the Dutch cause during the war by aiding Dutch people or Dutch institutions while not living in the occupied Netherlands. Visser't Hooft was promoted to Knight of the Order of the Netherlands Lion on 1 September 1948 for the special services he had provided for the development of the ecumenical movement, and was promoted to commander in $1965 .{ }^{3}$ In 1958 he received the Grand Cross of Merit with Star and Sash of the Federal Republic of Germany, and in 1959 he became an officer of the French Legion of Honour. In 1962 he received the Wateler Peace Prize for promoting peace through words, whether spoken or written, and the Grande Médaille d'Argent de la Ville de Paris.

Various schools and an institute in the Netherlands were named after him. ${ }^{4}$ Visser 't Hooft's portrait appeared on the cover of Time magazine in 1961. The accompanying article was called 'Second Reformation'. ${ }^{5}$ Several theological faculties and church programmes, including the Reformed church programme in Utrecht, offered Visser 't Hooft a chair in vain. Another moment of recognition was when he was awarded the Cross of Grand Commander of the Holy Sepulchre by the Ecumenical Patriarchate of Constantinople in 1963. That same year he received the Cross of Athos. He became a bearer of the Order of St. Vladimir of the Orthodox Church of Russia in 1964 and Commander of the Order of St. Andrew of the ecumenical patriarchate in 1965. Visser't Hooft, together with Cardinal Augustin Bea, was awarded the Peace Prize of the German Book Trade in 1966. Also in 1966, he received the Lambeth Cross, the highest distinction in the Anglican Church, from the Archbishop of Canterbury, and the Family of Man Award from the Protestant Council of New York City. Along with the former secretary-general of the United Nations, U Thant and Senator James W. Fulbright, he received the Grotius Medal for merit in the spreading of the notion of international law and became Honorary Commander of the Order of St. John in that same year. In 1967, he received the Danish Sonning Prize for his contribution to European culture. In that same year, he also became an honorary citizen of the City of Geneva and a member of the Order of the Prince of the Armenian Kingdom of Cilicia. ${ }^{6}$ In 1968, he was made a Knight of Justice of the Order

3 Utrechts Nieuwsblad, 2 September 1948.

4 There were schools named after Visser't Hooft in the Dutch towns of Leiden, Amsterdam, Castricum, Hoorn, The Hague, and Osdorp, and an ecumenical institute in Rotterdam, WCC 994.1.32/11.

5 Time, 8 December 1961.

6 The Dutch Minister of Foreign Affairs J.M.A.H. Luns took special measures to allow Visser't Hooft to become an honorary citizen of the City of Geneva in 1966 while retaining Dutch nationality. 
of Saint John. In 1969, he received the Distinguished Service Medal of the Pacific Lutheran University. In 1975, he received the Augustin Bea Prize, in 1976 the Prix de l'Institut des Sciences de la Paix in Strasbourg, and in 1977 the Hanseatic Goethe Prize. In 1982, he was awarded the Four Freedoms Award in Middelburg in the category of Freedom of Religion.

He could not remain indifferent to so many accolades. Even though he was unable to transfer his legacy properly and witnessed a decrease in the significance of the World Council in the last decades of his life, he knew that he had played a major role and was proud of that. All this attention meant recognition and personal acknowledgement as well as opportunities with respect to the major objective of continuously expanding the ecumenical network. As stated previously, however, he did not believe he was an original theologian or scholar. He believed he had been lucky that his qualities were valued during the phase that he had the health, inspiration, and power to assume many responsibilities. He felt that the ecumenical movement functioned as a supra-national family. That movement was expressed in the World Council as an instrument that served the church, to equip it for the service of the kingdom of God in the world. It was that task that he wished to carry out. Visser't Hooft once introduced himself as 'not the headmaster, not the general, but the secretary. The man of all jobs + odd jobs. ${ }^{7}$ When he described the work of the general secretary in his memoirs, he used the terms 'administrator', 'policy-making', 'chief liaison officer', 'minister of external affairs', 'interpretation of the nature and work of the World Council and of the ecumenical movement', and 'a good opportunity to oblige me to formulate in theological terms what I had learned in my daily work'. But he also spoke of resolving misunderstandings and giving lectures as 'a good opportunity to formulate in theological terms what I had learned in my daily work.' Above all, however, he regarded himself as the father of a large family, men and women from many nations and churches. ${ }^{8}$

\subsection{The Mirror of Rembrandt}

In his search for biblical imagery that could reach the youth from various countries linked to the YMCA and make them aware of European culture, Visser 't Hooft discovered the work of the famous $17^{\text {th }}$ century Dutch painter Rembrandt van Rhijn (1606-1669) as early as the 1920s. He

7 Visser't Hooft, notes for speech, Paris 1 August 1962, WCC 994.1.oo/3.1, 1962.

8 Visser't Hooft, Memoirs (1973), 344-346. 
heard that admirers of Rembrandt were impressed not only by the beauty of his painting but felt that the painter had unlocked the Bible in a special way. ${ }^{9}$ Rembrandt became for him an evangelist who used the medium of painting for his message, and, in Visser 't Hooft's eyes, his art became a message that transcended international boundaries. As a Dutchman, he understood the art of reaching youth from other countries using Rembrandt. When working for the YMCA, he recommended that youth leaders study art history. He felt that this would enable these youth leaders to alert young people to the idea that knowledge of works of art could introduce what was national and specific to the soul of a country to what he saw as a great international treasury of the arts. In an article in Jugend in Aller Welt that included illustrations of Rembrandt's work, he wrote:

The study of the art of the world furnishes us with the deepest insights into the relationships between the nations. No other domain of human life displays such a connection of national and international influences whose difference in direction and meaning can be contemplated. ${ }^{10}$

In the 1930s, Visser 't Hooft turned this thesis into a larger study. When possible, during his many travels he visited museums, particularly those that had one or more works by Rembrandt on display, as in Paris, Berlin, London, Kassel, and various locations in the United States. In 1937, Visser 't Hooft wrote a lecture on Rembrandt entitled 'Rembrandt et la Bible', which he continue to expand on throughout the years. " "I have ... a lecture with very beautiful lantern slides on "Rembrandt and the Bible". Naturally, this lecture covers all of Rembrandt's biblical works and discusses his Old Testament as well as New Testament paintings and etchings. I attempt to demonstrate how Rembrandt understood the Bible and how deeply he delved into it. ${ }^{12}$ In 1939, in a special issue of the YMCA magazine on the

9 Visser't Hooft, Memoirs (1973), 49-50.

10 Visser 't Hooft, 'Die Kunst, die Jugend und die Welt', 1925. 'Wohl mit die tiefsten Einblicke in die Beziehungen der Völker untereinander gewährt das Studium der Kunst in der Welt. Auf keinem anderen Gebiet des Menschenlebens zeigt sich eine solche Verbindung nationaler und internationaler Einflüsse, deren verschiedene Richtung und Bedeutung betrachtet werden kann.'

11 Visser 't Hooft, 'Rembrandt et la Bible', lecture 1937. Cf. Visser 't Hooft, 'Rembrandt als protestantischer Meister' (1938). Cf. Visser 't Hooft, 'Rembrandts Weihnachtspredigt', 1938. C. Loriaux (secretary of the Hollandse Club in Montreux) to Visser 't Hooft, 25 April 1939, World War II Records of the WCC, YDS-12.

12 Visser 't Hooft to C. Hammelburg, 27 March 1944. YDS-12, 61: 'Ik heb [...] een lezing met zeer mooie lantaarnplaten over "Rembrandt en den Bijbel”. Deze lezing gaat natuurlijk over 
Netherlands, which was published just prior to the large youth conference in Amsterdam, he wrote:

The life of Rembrandt ... offers us the spectacle of a man whose human nature, with all its richness and all its pride, is progressively mastered and moulded by the Word of God. In one of his last self-portraits, Rembrandt presents himself to us as the Apostle Paul reading the Bible. This unforgettable face shows us that he had to learn obedience through the things which he suffered, and tell us of many of the defeats of the natural man who was called Rembrandt. But this face also tells us that this man would say with St. Paul: 'In all things we are more than conquerors through Him Who loved us. ${ }^{13}$

The retired Dutch banker Isaac de Bruyn, who resided in Spiez in Switzerland, owned many etchings and old prints in addition to Rembrandt's famous self-portrait as the apostle Paul. Visser 't Hooft enjoyed being his guest. In May 1940, when the Netherlands was occupied by German troops, the preacher W. Cuendet presented Visser' $t$ Hooft with a print of an etching, probably from 1649. Based on Matthew 19, the print depicts Christ preaching. This is the so-called Hundred Guilder Print. When he looked at it, he realised that the most important thing was, as he said, that 'everything depends on the most unpretentious figure without beauty or outward power, who stands there in the centre."14 The etching shows the various reactions of people to Jesus. Visser't Hooft felt that Rembrandt's message here was that Jesus should not be viewed from a distance; rather one should participate in the circle around him, believe in him. But, as Visser 't Hooft saw it, as a preacher, this Jesus already stood figuratively in the shadow of the cross. He felt that to accept this Christ was to say 'yes' to a God who knew not only glory but also suffering. He was convinced that this was what Rembrandt wanted to teach him as a viewer. It was a message that, in his view, dovetailed with Karl Barth's theology, a call for people to convert and devote themselves to a compassionate God.

het heele Bijbelsche werk van Rembrandt en behandelt dus zijn oud-testamentische en zijn nieuw-testamentische schilderijen en etsen. Ik probeer daarbij te laten zien hoe Rembrandt den Bijbel begrepen heeft en hoe diep hij er in doorgedrongen is.'

13 Visser't Hooft, 'Notes on the Life of Rembrandt' (1939), 222, WCC 994.2.07/1.

14 C.M. de Vries, interview met Visser 't Hooft, in: 'Rembrandts weg tot het evangelie', IKOR Television, 15 July 1962, Sound and Vision Archives: 'alles afhangt van de onaanzienlijkste gestalte zonder schoonheid of uiterlijke macht, die daar in het centrum staat.' See also: Interview by R. Foppen with Visser 't Hooft, De Kerk Vandaag, NCRV Radio, 1 May 1982. Sound and Vision Archives. The self-portrait as the apostle Paul (1661) by Rembrandt was later donated to the Rijksmuseum in Amsterdam by De Bruyn. 
Figure 68 The Preaching Christ by Rembrandt, also called The Hundred Guilder Print, ca. 1647-1649

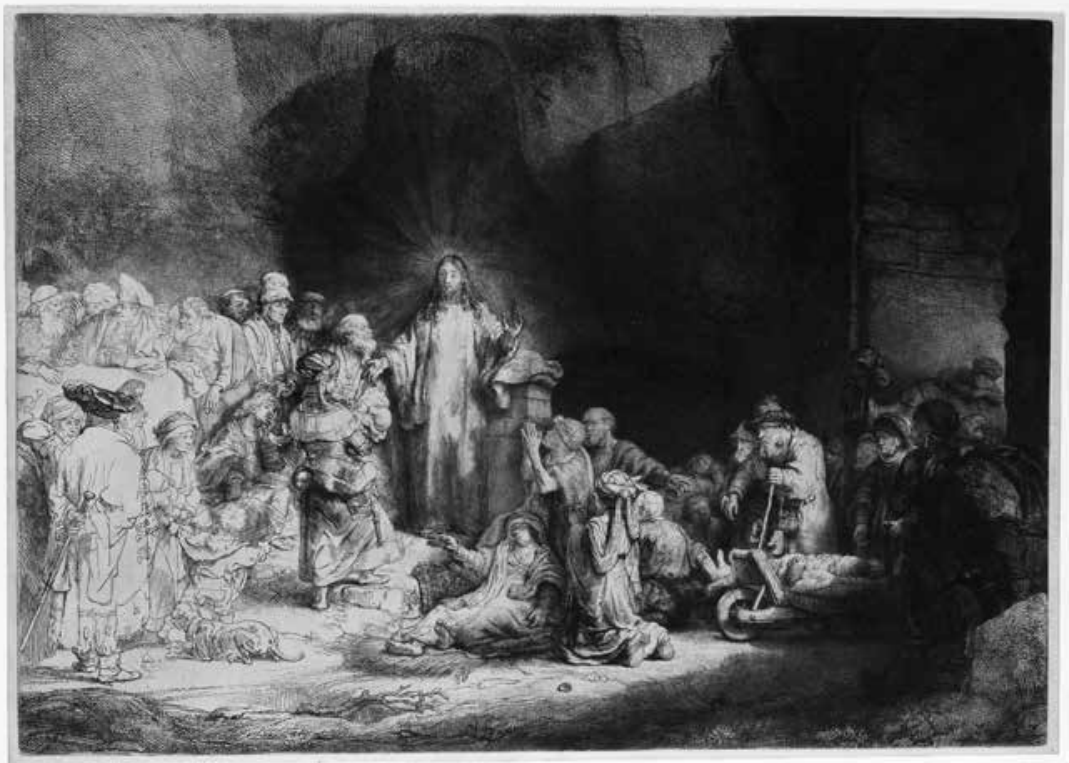

In 1955, he published a book in Dutch called Rembrandts weg tot het evangelie; the English version, Rembrandt and the Gospel, was published in 1960. ${ }^{15}$ In this book, Visser 't Hooft discusses, among other things, Rembrandt's painting Self Portrait with Saskia (generally dated 1636). In this painting he saw Rembrandt, who was completely taken up with partying, as 'a braggart who seemed to have the world in his pocket'. ${ }^{6}$ He was a passionate hedonist, with a superficial view of life that, Visser't Hooft felt, needed to be renounced and was indeed renounced after Saskia's death in 1642. Visser't Hooft added 1 John 2:16 as a marginal note in the book,

For all that is in the world, the lust of the flesh and the lust of the eyes and the vainglory of life, is not of the Father, but is of the world. (American Standard Version)

15 Visser 't Hooft, Rembrandt et la Bible (1947); Rembrandts Weg zum Evangelium (1955); Rembrandt and the Gospel (1960); Rembrandts weg tot het evangelie (1956). There were various television programmes based on the book, such as C.M. de Vries 'Rembrandts weg tot het evangelie', IKOR Television 15 July 1962, Sound and Vision Archives.

16 'Rembrandts weg tot het evangelie', IKOR television, 15 July1962, Sound and Vision Archives. 
And he posed the question: 'Is this real joy, or else "the lust of the eyes and the vainglory of life"?'17 Few Rembrandt experts today agree with Visser 't Hooft in regarding this painting as representing the painter's own worldly philosophy. Experts now believe that Saskia and Rembrandt were modelling for a scene from the parable of the Prodigal Son, a painting of which a part is missing. ${ }^{18}$

Visser 't Hooft's book about Rembrandt was ignored by art critics, certainly in the Netherlands, but was well received outside the circle of specialists both at home and abroad. For example, it was favourably reviewed in the journal Critisch Bulletin by the Dutch poet Gerrit Kamphuis, who could appreciate that Visser't Hooft presented Rembrandt as a typical Protestant artist who had been able to wrest himself from 'Roman baroque'. ${ }^{19}$ Rembrandt had had contacts with Jews, Roman Catholics, Mennonites, and Calvinists. The small circle who remained faithful to Rembrandt at the end of his life, even under difficult circumstances when he himself 'was no longer a church-goer', consisted of the most pietistic members of the Reformed Church. But because, in Kamphuis's view, Rembrandt presented the pure message of the Bible, his work acquired a universal meaning and Visser 't Hooft's ecumenical interpretation was the correct one. It was not a specific church or theological system that had guided the artist in this.

Visser 't Hooft did indeed see Rembrandt not as a Calvinist but as representing a universal biblical Protestantism. That view is still endorsed by some ${ }^{20}$ but Visser't Hooft gave this view a moral slant. He sharply contrasted Rembrandt not only with Peter Paul Rubens (1577-1640) as an exponent of the mostly theatrical baroque but also with the Renaissance painter Guido Reni (1575-1642), who he felt was too sentimental. In his eyes, both Rubens and Reni were examples of painting that focused on the outward aspect of people, whereas the cultured Rembrandt offered access to the inner life of human beings, which is where the life of faith occurs. Visser't Hooft believed that the young Rembrandt used the Bible only as a source for themes for genre paintings in a forced compromise between form, content, and the baroque style. In the post-1642 Rembrandt, however, he saw a deep personal engagement with Scripture.

17 Visser't Hooft, Rembrandt and the Gospel (1960), 130.

18 Namely, the younger son's squandering of his inheritance from his father, Luke 15:13.

19 Kamphuis, review, in: Critisch Bulletin (1956), 269.

20 Cf. Zell, Reframing Rembrandt (2002), 195 note 3. Cf. Perlove and Silver, Rembrandt's Faith (2009), 373-375. 
Here he was following the German art historian Carl Neumann who published a major Rembrandt study which portrayed the painter as a mystic. ${ }^{21}$ Visser't Hooft took over his idea that the religious art of especially the late Rembrandt was so biblical because it deviated from what was customary in the $17^{\text {th }}$ century. Neumann was the one who pointed out that Saskia's death was a major turning point in Rembrandt's life. At that point, faith in God took on a very different and more personal function. Visser 't Hooft spoke of a 'Copernican revolution' that occurred in the period 1642-1648 and that he believed was visible in Rembrandt's self-portraits.

Self-complacency, self-assertion, lust for pleasure disappear; his eyes become deeper and speak of suffering and loneliness. But at the same time a new strength appears in his features which is drawn from his victory over inner restlessness. ${ }^{22}$

While the Roman Catholic Rubens, as an artistic exponent of the CounterReformation, made Christ a 'triumphalist' hero, the Protestant Rembrandt seemed to be aware of the mystery of God's coming in the form of a servant. The older Rembrandt entered into the spirit of the Bible in the same way that Visser't Hooft himself wanted to. Rembrandt was not a systematician nor a person who was too focused on the institutional aspect of the church. Rather, he was someone who had come to know the depths of faith through crises. Visser't Hooft felt this approach to the painter was lacking in most of the Rembrandt literature. He was convinced, for example, that the great $19^{\text {th }}$ century Swiss art historian Jacob Burckhardt had not understood Rembrandt at all.

Although Visser't Hooft was a much sought after speaker on Rembrandt in the 1940s and 1950s - and not only in church circles - and his book sold well, his views influenced only a few serious Rembrandt studies. ${ }^{23}$ Even today, in contrast to Visser 't Hooft, there are hardly any contemporary experts who label Rembrandt's choice of subjects and his way of depicting biblical themes as his discoveries. Most of Rembrandt's biblical scenes are now viewed as impressions based on the work of illustrators of the Bible, such as Maerten de Vos and Maerten van Heemskerck. ${ }^{24}$ The division of

\footnotetext{
21 Visser't Hooft, Rembrandt and the Gospel (1960), 20 and 108. Cf. Neumann, Rembrandt (1922). Visser't Hooft used the vermehrte Auflage (expanded edition) of 1905 .

22 Visser 't Hooft, Rembrand and the Gospel (1960), 12.

23 Zeilstra, interview with E. van de Wetering, 29 January 2016. An exception is the Lutheran minister and art historian Christian Tümpel, Rembrandt (1986).

24 Tümpel, Rembrandt (1986), 150 and 171.
} 
the painter's life into two periods, with the pre-1642 Rembrandt seen as a painter of the outward aspects of human life, as a representative of the baroque with great public success, has generally been abandoned. According to the view of Visser 't Hooft, it was only after 1642 that Rembrandt turned away from the baroque and became a painter of the inner life. The pursuit of success was supposed to have given way to profound feeling. This way he tried to explain the assumed contemporary misunderstanding of the later Rembrandt. Around the year 1900, a number of authors adhered to this view, including the Dutch art historian and museum director Frederik Schmidt Degener, who was popular in his time and whom Visser 't Hooft regularly quoted. ${ }^{25}$ Schmidt Degener believed that the older Rembrandt led an isolated life, and it was in this phase that he arrived at his most profound interpretations of the Bible, with only a small circle of friends who valued his message. Visser't Hooft concurred with this view:

Did these friends grasp the true significance of Rembrandt's art? We can only say that at least they grasped more of it than their contemporaries. ... But at least it means that in Rembrandt they not only saw the great master of the technique of painting, but also that they became aware that he was the bearer of a message, and of a message, moreover, with which he had been inspired from above, like St Matthew in his painting. ${ }^{26}$

This view of a late or mature Rembrandt as a deeply religious non-conformist says more about Visser 't Hooft than it does about Rembrandt. In turn, Schmidt Degener bases his view on the biography of Rembrandt by Carl Neumann mentioned earlier. The latter calls the Rembrandt after 1642 the 'painter of the soul'. Neumann postulates that the Rembrandt after 1642 shows a certain purity that was also present in the late Middle Ages and can be contrasted with the Renaissance and the baroque style. What makes Rembrandt unique is the fact that he succeeded in overcoming the baroque style and embraced a pure spirituality rooted in the Middle Ages with a disinterested religious orientation.

This is viewed as a $19^{\text {th }}$ century construction today. ${ }^{27}$ According to the Rembrandt expert Ernst van de Wetering, one can observe at most a

25 Schmidt Degener, Rembrandt und der holländische Barock (1928). Idem, 'Rembrandt en Vondel', in: De Gids, Vol. 83, 1919, 222-275

26 Visser 't Hooft, Rembrandt and the Gospel (1960), 102. Zeilstra, interview with E. van de Wetering, 29 January 2016.

27 Cf. Emmens, Rembrandt en de regels van de kunst (1979), 19 and 23f.; Slive, Rembrandt and his critics (1953). 
difference in stress: the young Rembrandt appears to have had more of an eye for the physical, for movement, dynamics, and thus for the theatrical. The older Rembrandt, on the other hand, was fascinated by the spiritual and subtle expressions. ${ }^{28}$ The $19^{\text {th }}$ century cult of the artist as a misunderstood genius is seen as the background for what is called the increasing 'Christianising of the image of Rembrandt'. ${ }^{29}$ Around 1640, Dutch art moved towards the classical style. The fascination with movement, which Rembrandt also exhibited, gave way to what is known as a lighter and more muted way of painting..$^{30}$ Van de Wetering prefers not to speak of a development or change in style. Rather, what he sees in Rembrandt is a radical new approach to the question of the imagination. By using an unconventional method of applying paint, thereby allowing for the factor of chance, and the intentional 'incompleteness' of some details, he succeeded in creating a convincing naturalness that brings the observer very close to the scene depicted..$^{31}$ The assertion that the older Rembrandt was particularly occupied in his art by the representation of universal truth and higher spiritual concerns cannot be proven. He always paid a great deal of attention to concrete history. ${ }^{32}$

Visser't Hooft was aware of the criticism by art critics when writing his book but did not think that Schmidt Degener's main thesis had been refuted. ${ }^{33}$ The presumed division in Rembrandt's life provided Visser 't Hooft with a tempting framework for interpretation and presentation - and not only for Rembrandt's life. The element of a break, conversion or penance is central here, followed by devotion and commitment in light of God's mercy. He recognised this in the parable of the Prodigal Son and in the life of the apostle Paul and also recognised it in Karl Barth's theology. It was this framework that gave him a way to understand the lives of people and history. It also gave him something to hold on to personally, and it aided him in the structure of his many lectures because it provided a certain clarity even when all kinds of forces were working together in a complex and murky field of tension. Rembrandt thus provided material for Visser't Hooft's pedagogical framework. His view of Rembrandt is above all an illustration of Visser't Hooft's conviction that the biblical message is the foundation for a meaningful life marked by a real contrast between joy and sorrow. And yet, there was something

Van de Wetering, Rembrandt. The Painter Thinker (2016).

29 Emmens, Rembrandt en de regels van de kunst (1979), 35. For a modern view of Rembrandt in line with Visser 't Hooft's, see Perlove, Pursuit of Faith (2010), 31.

30 Tümpel, Rembrandt (1986), 108-109.

31 Van de Wetering, Rembrandt. The Painter Thinker (2016), 223-281.

32 Tümpel, Rembrandt (1986), 126.

33 Visser't Hooft, Rembrandt and the Gospel (1960), 110. 
else. Visser 't Hooft felt a strong affinity with Rembrandt, observing in him a love for the Bible that affected him deeply. It was Visser 't Hooft's view of Rembrandt that was key to understanding his own life. For Visser 't Hooft, Rembrandt himself was an icon of the human being before God.

\section{4 'Mein Sach' auf Nichts gestellt'}

Visser't Hooft saw in Rembrandt a supremely gifted person who was perhaps misunderstood by many but who lived like a king. This was the type of person he himself wanted to be. He could be seen as arrogant: while some people looked up to him, were even afraid at times of those piercing eyes that looked right through you, and many respected him without really knowing him, others saw Visser't Hooft as too self-confident. It could hurt if someone felt Visser't Hooft did not acknowledge him or her. For example, Hebe Kohlbrugge, a courier on the Swiss Road, felt she was not taken seriously enough by Visser 't Hooft in resistance work and, looking back later, called him 'very selbstbewusst' (self-assured), and she did not mean that in a positive sense. ${ }^{34}$ For others, the firmness with which he acted gave an impression rather of someone who had persevered and achieved results while others got stuck in details and objections. In 1971, Adolf Freudenberg and Hans-Heinrich Harms, both of whom worked with him intensely for a long time, typified Visser 't Hooft as someone who thought very quickly and was always a few steps ahead of everyone else.

Visser 't Hooft thinks and responds extraordinarily quickly and is in control of himself. Ideas, which he has in abundance, are cleverly and quickly converted into clear plans and decisions; he is able to give a staff member an assignment in one single sentence that will keep him, and others, occupied for a long time. He is impeccably business-oriented without being spiritless, for he can also be incensed or cold. ... He never got lost in details and processed an incredible amount of post and memos at an amazing speed. He listened well, because he took the people and the cause he represented seriously. Those who valued him and faithfully served the one cause that mattered were given royal independence in the work they did in Geneva. ${ }^{35}$

35 Freudenberg and Harms, 'Willem A. Visser 't Hooft', 1971, 306. 'Visser 't Hooft denkt und reagiert ungewöhnlich rasch und ist Herr seiner selbst. Gedanken, die ihm in reichlicher Fülle 
Those staff members whom he respected had a great deal of freedom in doing their work. Many of them, some of whom he worked with for decades, had almost unlimited admiration for him, such as Suzanne de Diétrich (18911981), secretary of the WSCF 1935-1946 and later director of the Ecumenical Institute in Bossey. In her opinion, students always felt at ease with Visser 't Hooft. ${ }^{36}$ De Diétrich recalled her experiences with Visser 't Hooft in the 1930 in particular. At that time, policy and the big picture were less important and personal faith was stressed. From 1934 on, she and Visser't Hooft ensured that prayer once again played an important role at the conferences, which included compiling a small book on personal and communal prayer, Venite adoremus. ${ }^{37}$ In an article on the occasion of Visser 't Hooft's $50^{\text {th }}$ birthday, De Diétrich described him as someone who had been selected by God himself for ecumenical work, someone who did not do this work because he himself wanted to but acted out of obedience to God. For Visser 't Hooft himself, the conviction that he was acting out of obedience to God most certainly played a role. Upon Hans Hoekendijk's return in 1946 to the Netherlands from India after disappointing experiences, he wrote to him:

And yet, there is a different kind of comfort in the fact that there appear to be tasks everywhere in the Church of Christ and in the fact that these do not depend on their location but on obedience. ${ }^{3}$

Everyone who worked with Visser 't Hooft knew that he valued initiative, zeal, discipline, and a punctual daily structure. De Diétrich had difficulty walking, and Visser 't Hooft in his car picked her up every day promptly at six minutes to nine in 1930s so that she could arrive at the WSCF office at Rue Calvin, number 13, at nine o'clock precisely.39 Later on, when the

zufliegen, wurden herzhaft und schnell zu klaren Planungen und Entschlüssen gestaltet; er konnte einem Mitarbeiter mit einem einzigen Satz eine Aufgabe stellen, die diesen und nicht nur diesen lange in Atem hielt. Er ist unbestechlich sachlich, ohne temperamentlos zu sein, denn zornig und eiskalt kann er auch werden. [...] Er versank nie im Detail und arbeitete sich durch die beängstigende Fülle der Eingänge und Memoranden in verblüffendem Tempo hindurch. Er hörte gut zu, weil er den Menschen und die von ihm vertretene Sache ernst nahm. Wer ihn gelten ließ und zuverlässig der einen Sache diente, um die es geht, konnte in Genf mit königlicher Selbständigkeit arbeiten.'

36 De Diétrich, 'Visser 't Hooft als algemeen secretaris van de WSCF' (1950), 430.

37 Weber, H.-R., The Courage to Live (1995), 80-82.

38 Visser't Hooft to J.C. Hoekendijk, 16 September 1946. WCC general correspondence 661. 'Een grote troost is echter nu ook weer op een andere manier in het feit, dat er in de Kerk van Christus overal een taak ligt en dat het ten slotte niet van de plaats afhangt, maar van de gehoorzaamheid.' 39 De Diétrich, 'Visser 't Hooft als algemeen secretaris van de WSCF' (1950), 430. 
World Council was located at the Route de Malagnou address, he arrived daily (when not abroad) at 8:30 a.m. in his little Vauxhall and went home punctually at 5 p.m. He generally retired for the night at 10 p.m. when he was at conferences. His strict faith discipline included several simple personal rituals. Before getting into bed, he said his evening prayer, often kneeling at the side of his bed. Every day, before going to sleep and when rising in the morning, he read a passage from the Bible, preferably from his own personal copy of the Greek New Testament. ${ }^{40}$

When Visser't Hooft was asked by the column 'Ex Libris' of the American magazine The Christian Century to respond to the question, 'What books did most to shape your vocational attitude and your philosophy of life?', he listed the novels by Dostoyevsky, Pascal's Pensées, Barth's Epistle to the Romans and Credo, Julius Schniewind's commentaries on Matthew and Mark, E.C. Hoskyns and F. Noel Davey's The Riddle of the New Testament, O. Noordmans's Herschepping, William Temple's Readings in St.John's Gospel, Dietrich Bonhoeffer's Ethics, and Buber's Die Schriften über das dialogische Prinzip (including Ich und Du)..$^{4}$ This was only the tip of the iceberg of the books he had read and from which he had processed aspects in his work. Konrad Raiser, one of Visser 't Hooft's later successors as general secretary of the World Council, spoke of 'a theologian of extraordinary erudition'. ${ }^{42} \mathrm{An}$ academic career would certainly have been a possibility but, according to De Diétrich, Visser't Hooft was not interested in knowledge for knowledge's sake - he was more interested in the application. ${ }^{43}$ De Diétrich described his style as 'dynamic, an atom bomb, but a constructive atom bomb.' Visser 't Hooft himself did not believe he was an original scholar but rather someone who worked with the ideas of others. The Dominican René Beaupère felt Visser't Hooft was more of a teacher and someone who prioritised vigilance: 'a theological sentinel'. ${ }^{44}$ Theological dialogue was important, but not the objective. His objective was to make the unity that focused on Christ visible, via revitalised churches that understood that their raison d'être was to be a part of the world church and were actively committed to the unity of church and society.

40 The Greek New Testament Visser't Hooft would read from daily is now in the possession of his grandson, Caspar Visser't Hooft.

41 The Christian Century, vol. 80, no.18, May 1963, 583.

42 Raiser, 'Le pasteur Willem Visser't Hooft, pionnier de l'oecuménisme Genève-Rome', 2003, especially 33: 'un théologien d'une éruditon extraordinaire'.

43 De Diétrich, 'Visser't Hooft als algemeen secretaris van de WSCF', 1950, 431.

44 Beaupère, 'Rencontres avec W. Visser't Hooft', 2003, especially 40: 'un veilleur théologique, une sentinelle'. 
He enjoyed speaking to others about their faith and touched the hearts of many, but, strangely enough, Visser 't Hooft was shy when it came to discussing his own personal faith experience. Nonetheless, at the same time, he made unexpected and enigmatic statements that allowed glimpses into his heart. While travelling in 1968, he stopped in to visit his sick niece Clan, one of the daughters of his brother Hans, a general practitioner who lived in Velp. He sat down beside her bed and said: 'There are three things that you must consider. You have the time to do so right now.' The first was: 'Ich habe meine Sache auf Nichts gestellt.' The second was: 'Be thankful for small mercies.' And the third: 'In an absurd world, only an absurd message of salvation can be believed.' These words made a deep impression on Clan, and she wrote them down in the Bible she took with her when she travelled. She enjoyed going to the church in Rozendaal where the well-known poettheologian Willem Barnard (1920-2010) served as assistant pastor and gave poetically inspired sermons. She once took her uncle Wim to a service that Barnard led. His comment - in French - was as sobering as it was typical: 'Magnificent! But it is not a sermon.'45

The line 'Ich hab' mein' Sach' auf Nichts gestellt' (On nothing have I set my heart) is the opening line of a poem by Goethe, 'Vanitas! Vanitatum vanitas!', a parody on the $16^{\text {th }}$ century Lutheran hymn 'Ich hab mein Sach Gott heimgestellt' (My life I now to God resign) by Johannes Leon. Goethe's text was set to music by Louis Spohr (1784-1859) and became a students' song proclaiming that the entire world belongs to the free person. No money, possessions, women, travelling, fame, or honour can compete with that. The German philosopher Max Stirner (Johann Caspar Schmidt, 1806-1866) elaborated on that idea in his book Der Einzige und sein Eigentum (1844):

My concern is neither the divine nor the human, not the true, good, just, free, etc., but solely what is mine, and it is not a general one, but is - unique as I am unique. Nothing is more to me than myself! ${ }^{46}$

The question is what exactly Visser't Hooft meant in his conversation with Clan in 1968. We should recall that it was a time in which students wanted to go their own way, and it was in that same summer that he gave his famous

45 Zeilstra, interview with J.C. Visser 't Hooft, 26 September 2013. 'C'est magnifique, mais ce n'est pas un sermon.'

46 Stirner, The Ego and his Own, https://theanarchistlibrary.org/library/max-stirner-the-egoand-his-own; Der Einzige und sein Eigentum (1844). 'Meine Sache ist, weder das Göttliche, noch das Menschliche, ist nicht das Wahre, Gute, Rechte, Freie usw., sondern allein das Meinige, und sie ist keine allgemeine Sache, sondern ist einzig, wie ich einzig bin. Mir geht nichts über Mich.' 
speech at the Assembly in Uppsala. He wanted to give a young generation the room to explore the world themselves, but he also felt that thankfulness for small signs of mercy and trust in God were essential.

\subsection{Accolades and Critiques on the Occasion of his Death}

When he died in July 1985, many people looked back on the life of Willem Adolf Visser 't Hooft from many different points of view. After the funeral Mass for Cardinal Bea in 1968, Pope Paul VI had called Visser 't Hooft the 'guardian angel of the World Council'. ${ }^{47}$ In 1985, Visser't Hooft was even compared to the Pope himself, usually in a positive sense but also with a certain negative undertone. This was the case in his homecountry the Netherlands as well as elsewhere. M.H. Gans, who had collaborated extensively with Visser't Hooft during the war on behalf of the Jewish refugees, spoke of 'the Pope of the Protestants. ${ }^{8}$ The journalist Frits Groeneveld referred to him as 'the diplomat of God' and 'the Pope of ecumenicity'. ${ }^{49}$ The journalist Ben Maandag of the Dutch newspaper Het Vrije Volk went just a bit further. He wrote: 'Visser't Hooft was ecumenicity'. $5^{0}$ In the Leeuwarder Courant, Visser 't Hooft was called the 'mainspring behind the World Council'. ${ }^{51}$ Other similar characterisations were: 'Father of Ecumenism' or 'Mister Ecumenicity', 'Mr. Omnipresent' and 'Mr. Omnicompetent' and the representative of the 'Dutch spirit'. $5^{2}$ Nederlands Dagblad was rather caustic and listed his failures in particular and spoke of the suspicion that the unity for which Visser't Hooft's World Council had fought at one time was not unlike the unity sought at the time of the Tower of Babel. ${ }^{53}$ The term 'architect' of the World Council

\footnotetext{
47 Visser't Hooft, Memoirs (1973), 337.

48 Gans, in: Nieuw Israelitisch Weekblad, 26 July 1985.

49 F. Groeneveld, in: NRC Handelsblad, 5 July 1985: 'Hij gedroeg zich als een hoge diplomaat - als vertegenwoordiger van het Koninkrijk Gods op aarde.' (He behaved as though he were a senior diplomat - as a representative of the Kingdom of God on earth.)

50 Maandag, in: Het Vrije Volk, 5 July 1985: 'Hij sprak nooit van bovenaf, probeerde alleen maar te verzoenen, was een eenvoudige vent, zonder kapsones, maar hartstochtelijk bewogen, je mag zeggen bezeten door de gedachte, dat de scheidingsmuren tussen de kerken afgebroken moeten worden.' (He never spoke down to people, he only tried to reconcile, without being full of himself, yet passionately moved - you could even say possessed - by the idea that the dividing walls between the churches had to be torn down.)

$51 \quad$ Leeuwarder Courant, 5 July 1985.

52 Barkey Wolf, in: Accent, 25 December 1971.

53 Nederlands Dagblad, 6 July 1985: 'Er zit iets erg verdrietigs in het vele werk dat dr. Visser 't Hooft gedurende zijn "leven in de oecumene" heeft verricht.' (There is something sad about all of the work that Dr Visser 't Hooft did during his 'life in ecumenicity.')
} 
was used often. The New York Times called Visser't Hooft a 'bureaucrat' with major influence and praised him for his carefully constructed network of ecumenical contacts:

His life was testimony to the proposition that a good bureaucrat in the church can exercise one of the most powerful of all ministries, and that personal contacts, patiently and generously cultivated, are a potent force for the shaping of history. ${ }^{54}$

In this paper, he was praised as an engaging speaker with the allure of a statesman, someone who cared little for outward show: 'He was a man of striking appearance and possessed unusual physical alertness and energy even in later years.' That there was an intimidating side to his character had not escaped the newspaper. Another contribution in the same paper described Visser 't Hooft as 'A lean, lanky man with a jutting jaw'.55

Statesman, rather than cleric. He smoked and drank, often having a drink or two of vodka before dinner and a glass of beer before bed, and preferred dark conservative business suits to clerical garb..$^{6}$

Several newspapers called Visser 't Hooft a 'diplomat', in both a positive and a negative sense. ${ }^{57}$ The journalist Ko Colijn called Visser't Hooft a man possessed, a go-getter by the grace of God, always on the go. He remembered that Visser't Hooft had been called 'a modern Odysseus' at the presentation of an honorary degree in Oxford and was convinced that his death meant the close of an ecumenical era. ${ }^{8}$

In 1985, Albert van den Heuvel, who had long worked with Visser 't Hooft, called him both 'a brilliant strategist' as well as 'a difficult person' and nonetheless someone whose suitcase he would carry to the end of the world if necessary. Visser 't Hooft was, in his opinion, 'hypercritical' but, deep down, a 'shy man' who could also be warm and was true to - often very old - friendships. He remembered Visser 't Hooft's own words: 'I was the hard worker, the one who wanted to get an important job done.' In addition to diplomat, Van den Heuvel also called him a democrat and federalist, 
left of centre and true to the royal Dutch House of Orange. ${ }^{59}$ Henk Muller referred in de Volkskrant to the impatience that Visser't Hooft himself was well aware of and to his long speeches and spoke of 'a diplomat of the old school' who had insisted on remaining silent about religious persecutions in the Soviet Union at the Assembly of Nairobi in $1975 .{ }^{60}$ Robert Kroon of De Telegraaf compared Visser't Hooft with Dutch diplomats like Gerrit Jan van Heuven Goedhart, Adriaan Pelt, the Dutch director of the European office of the United Nations, and Joseph Luns, who had been the Dutch Minister of Foreign Affairs for years. ${ }^{61}$

The Methodist staff member of the World Council, Betty Thompson, referred to Visser 't Hooft as an 'ecumenical mover and shaker' as well as 'something of a Jehovah-type father figure'. For Thompson, he was representative of what she called the 'theological tribe of Barth, Brunner, Niebuhr'. She found Visser 't Hooft to be 'acerbic, charming, diplomatic, blunt, shy and assured. ${ }^{62}$ He was a Christian 'with a lively mind who was prepared to do the hard work necessary for the realization of some of his dreams.' She remembered how she and one of her colleagues were given a thorough dressing down by Visser 't Hooft, wearing an old-fashioned swimming suit - he loved swimming -,

for the 'obscene' act of eating ice cream cones in public at a resort in Denmark where the Central Committee was meeting. At the time he was wearing a moth-eaten one-piece bathing suit left over from the '2os - an outfit that seemed to us more deserving of the term. ${ }^{63}$

The journalist Oene Bergher was very critical in De Tijd. He felt that Visser 't Hooft was 'an authoritarian figure', 'a world big-boss', 'more of a general than a secretary' who feigned modesty. ${ }^{64}$ According to Bergher, Visser 't Hooft himself was guilty of heresy. He was not helpful at all, and he made sure that the majority of the World Council did not pursue a 'responsible society' if this was to be at the cost of its own power. Bergher held Visser 't Hooft personally responsible for the misuse of his words about heresy in 1968. He saw him as the failing official who, at the time, stood in the way of

59 Van den Heuvel, in: Trouw, 5 July 1985. See also: Interviews with H. Berkhof, A.H. van den Heuvel, and H.M. de Lange, Brood en Spelen, IKON radio, 6 July 1985, Sound and Vision Archives.

6 o Muller, in: de Volkskrant, 5 July1985.

61 Kroon, in: De Telegraaf, 8 July 1985.

62 Thompson, in: The Christian Century, 17-24 July 1985.

63 Ibid.

64 Bergher, in: De Tijd, 26 July 1985. 
succession by a person from the Third World. He remembered asking Visser 't Hooft whether the international ecumenical monastic community of Brother Roger Schutz in Taizé could be a bridge between Rome and Geneva. Visser't Hooft had nothing good to say about Taizé and said: 'They cannot go around Geneva,' which sounded very arrogant to Bergher. At that time, so soon after his death, Bergher was one of the few who took such a negative view of Visser 't Hooft's attitude and actions. But even later, there were few who spoke this critically about Visser 't Hooft. As time passed, a more relativising tone became apparent in the assessments, although years later, in 1998, when de Volkskrant journalist J.J. Lindner was asked to characterise Visser't Hooft, he recalled the painful metaphor used by Karl Barth in 1935 when he compared ecumenicity to a circus and called Visser 't Hooft the indispensable 'equerry of the circus of ecumenicity'. ${ }^{65}$

Albert van den Heuvel called the old Visser't Hooft 'the conscience of the World Council' who was always quick to use the word 'nonsense'.66 But, in his opinion, Visser 't Hooft could also admit to having lost arguments. 'He would grumble some at first, but once it became apparent that you were right, he would give in.'

I will not make a saint of him, he was not a great psychologist when dealing with people. He was rather rough with those who needed a pat on the back. His liberal background helped him deal with culture and liberalism. He was very interested in philosophy. Holidays were short. Having a remarkable circle of friends due to his honorary degrees, he discussed books with all of the great theologians of his time, and had the memory of an elephant. He wasted no time; during meetings he would often work on a book, visit museums at conference locations, no small talk, swimming ... hesitant to display emotions. ${ }^{67}$

According to Van den Heuvel, Visser 't Hooft's best sermons were at funerals. When the little daughter Suzanne of Boudewijn and Jet Sjollema-van Sandick

65 Lindner, in: de Volkskrant, 19 August 1998.

66 R. 't Sas, interview with A.H. van den Heuvel, 1983, WCC 994.1.36/1.

67 Ibid.: 'Ik zal geen heilige van hem maken, een groot psycholoog in de omgang met mensen was hij niet. Iemand die het meer moest hebben van een schouderklop, daar was hij nogal ruw mee. Zijn vrijzinnige achtergrond hielp hem ook met cultuur en vrijzinnigheid om te gaan. Hij had een grote belangstelling voor filosofie. Vakanties waren kort. Merkwaardige vriendenkring door vele eredoctoraten, besprak zijn boeken met alle grote theologen van zijn tijd, een ijzeren geheugen. Hij morste geen tijd; zat tijdens vergaderingen vaak aan een boek te werken, museumbezoek in conferentieplaatsen, geen small talk, zwemmen [...] schroom gevoelens te tonen.' 
died after being hit by a train, Visser 't Hooft sympathised deeply. He led the funeral service on 12 January 1963 and spoke about Job who was assured of God's love even though his many questions were not answered. ${ }^{68}$

The very same Visser 't Hooft could be quick-tempered. His daughter Anneke remembered how he, wanting to rest at home after a long trip, could explode when the children were noisy. At times he would be standing yelling at the window if the neighbour's dog was barking. World Council members Albert van den Heuvel and Boudewijn Sjollema recalled that they could often tell by the tea cup held in Visser't Hooft's hand that a fit of rage was about to occur; it would begin to shake as he became wound up. ${ }^{69} \mathrm{But}$ outbursts could clear the air and, some time later, the terrified conversation partners would be sharing a table with Visser 't Hooft, enjoying a glass of good wine while laughing and telling anecdotes.

Frans Bouwen, the theology student from Leiden, did an internship at the World Council in Geneva in 1980 and was looking for a room. During the tea break, Visser't Hooft offered to let him stay in his house if he would be willing to cook for him..$^{70}$ Dinner had to be on the table at exactly 6.30 p.m. The conversation always concerned ecumenicity, never the weather or the wine. Visser' $t$ Hooft was often curt and demanding but, strangely enough, became shy if things seemed to become personal. As soon as the conversation turned to something that really interested him, his eyes began to twinkle, he would ask questions and could then talk with great detail, immediately and with humour. In 1984, Bouwen was once again a guest of the old Visser 't Hooft, but this time with a group of young people from the Kloosterkerk in The Hague. One of the young people asked: 'What is the "most beautiful thing" that you every saw or experienced?' Visser't Hooft replied:

I find that impossible to answer. You would need to categorise 'beautiful'. 'Beautiful' in your private life, 'beautiful' in your professional life. For me, the high point of ecumenical life was the youth conference of 1939 in Amsterdam. Young people from around the world had gathered there. We had very good representation from Africa and Asia. We knew and felt that the world was about to explode. It was ... three weeks before the war broke out. I had met Dietrich Bonhoeffer shortly before and been

68 Visser 't Hooft, 'Toespraak 12 januari 1963', WCC 994.2.19/3. Zeilstra, interview with B.C. Sjollema and H.J.M. Sjollema-van Sandick, 4 February 2015. Sjollema, Never Bow to Racism (2015), 23.

69 Zeilstra, interview with A.H. van den Heuvel, 23 April 2013. Beaupère, 'Rencontres avec W. Visser't Hooft', 2003, 39.

70 Bouwen, in: Tijd en taak, 20 July 1985. 
well informed by his friends in the German army, who said that Hitler would attack Poland in September. The atmosphere was such that we had gathered together and experienced the deep unity of people who would be separated, some would disappear in the war, some end up in concentration camps, others in prisons. I will never forget how we sang 'À Toi la Gloire' in the Koepelkerk in Amsterdam. I have never sung it again in the same way. I thought the roof would fly off the building. ${ }^{71}$

\section{A little while later, Rembrandt prints were passed around while Visser 't Hooft spoke of the old days.}

71 Ibid.: 'Dat vind ik eigenlijk een onmogelijke vraag. 'Mooi' zou je, eigenlijk in categorieën moeten verdelen. 'Mooi' in je privé-leven; 'mooi' in je professionele leven. Het hoogtepunt in het oecumenisch leven is voor mij de jeugdconferentie van 1939 in Amsterdam. Daar waren we met de jeugd van de hele wereld bijeen. We hadden een zeer goede vertegenwoordiging van Afrika en Azië. We wisten en we voelden dat de wereld op springen stond. Het was [...] drie weken voor de oorlog uitbrak. Ik had kort daarvoor Dietrich Bonhoeffer ontmoet en goede inlichtingen gehad van zijn vrienden in het Duitse leger, die zeiden dat Hitler in september Polen zou aanvallen. het was in die sfeer dat we toen bijeen waren en die diepe eenheid beleefden van mensen die uit elkaar geslagen zouden worden en waarvan er een aantal in de oorlog verdwenen zijn, sommigen in concentratiekampen, anderen in gevangenissen. Ik vergeet nooit hoe we daar in de Koepelkerk in Amsterdam het 'À Toi la Gloire' zongen. Ik heb het nooit meer zo gezongen als toen. Ik dacht dat het dak eraf zou barsten.' 
